\title{
Hibernation Period in Some Land Snail Species (Gastropoda: Helicidae): Epiphragmal Structure and Hypometabolic Behaviors
}

\begin{abstract}
Hülya Şereflişan ${ }^{1, a, *}$, Önder Duysak ${ }^{1, b}$
${ }^{I}$ Faculty of Marine Science and Technologies, Iskenderun Technical University, 31200 Iskenderun/Hatay, Turkey *Corresponding author

A R T I C L E IN F O A B S T R A C T

Research Article

In this study, the hypometabolism behavior, epiphragm formation process, and the mineral composition of the epiphragmal structure of the Helix pomacella, Eobania vermiculata, Helix melanostoma, and Helix asemnis land snails were investigated during the hibernation period. 100 snails selected among mature individuals, 25 from each species, were collected from nature for the research. The snails were placed in four 50x50x5 cm pans containing 20-cm-deep humus soil. Snails were fed with lettuce by free feeding until the hibernation period. Hypometabolism behavior of snails that had hibernated between November and December 2018, and January and February 2019 were examined as entering the hibernation stage, hibernation stage, and leaving the hibernation stage. The ionic concentration (Calcium, Iron, and Phosphorus) of the epiphragm layer formed during the hibernation process was analyzed, its formation duration, and its degradation at the end of the hibernation period were examined. In the study, it was determined that the weight before hibernation reduced by $18-22 \%$ in all examined species ( $H$. pomacella, E. vermiculata, $H$. melanostoma, and $H$. asemnis). The highest values in terms of epiphragm formation duration $(19 \pm 0.30$ days $)$, weight $(0.41 \pm 0.26 \mathrm{~g})$, and thickness $(0.310 \pm 0.22 \mathrm{~mm})$ were determined in $H$. asemnis. In terms of the ionic concentration, the highest Calcium level was determined in $H$. asemnis $(29.96 \pm 0.12 \mathrm{mg} / \mathrm{g})$ while the highest Phosphorus level $(4.02 \pm 0.20 \mathrm{mg} / \mathrm{g})$ was determined in E. vermiculata, and the highest Iron content was found in H. pomacella $(19.50 \pm 0.33 \mathrm{mg} / \mathrm{g})$. The degradation duration of the epiphragm layer at the end of hibernation was determined the longest in E. vermiculata (7 days) whereas the shortest in $H$. pomacella (3 days). As a result of the present research, it was seen that the epiphragm layer is important for snails in terms of a sustainable life cycle and that the ecological tolerances of snails depend on the epiphragmal structure.
\end{abstract}

hulya.sereflisan@iste.edu.tr

D.tps://orcid.org/0000-0002-2510-3714

bonder.duysak@iste.edu.tr

https://orcid.org/0000-0002-7484-3102

This work is licensed under Creative Commons Attribution 4.0 International License

\section{Introduction}

Land snails belong to the second-largest branch of the animal kingdom, Mollusca, with approximately 80,000 members (Adeyeye and Afolabi, 2004; Akman et al., 2005). The Helicidae and Achatinidae families are the two most common families of gastropods regarding the production and consumption of land snails (Abdussamad et al., 2010). Tropical animals overcome this process by preventing physicochemical changes during extreme temperature increases and decreases in different seasons (Hermes-Lima et al., 1998; Odiete, 1999; Storey, 2001). Water, temperature and humidity have an effect on changes in the behavior and physiology of land snails (Prior, 1985; Cook, 2001; Storey, 2002; Giokas et al., 2007). In this manner, the determination of species-specific habitat requirements can be used to predict the response of snails to changing environmental conditions in the future (Storey, 2002). In cases where temperature values are extremely high and low, snails draw themselves to the extreme corner within the spiral structure of their shells and form the epiphragmatic layer to close the aperture opening (HermesLima et al., 1998; Şereflişan, 2019). Estivation (summer sleep) and hibernation (winter sleep) period, the epiphragmal structure formed to prevent excessive water loss or prevent freezing of body fluid is opened at intervals to provide rapid $\mathrm{CO} 2$ and $\mathrm{O} 2$ exchanges (Hermes-Lima et al., 1998). It has been reported that the growth, movement, and reproductive behaviors of the snails were reduced during the estivation and hibernation period in which snails can survive for a long time without water and nutrients (Akinnusi, 1998; Malcolm et al., 2006; Şereflişan, 2019). During this period, snails use their body reserves at a very low rate (Omoyakhi, 2007). The epiphragmal structure plays a major role in circumventing the estivation and hibernation periods (Şereflişan, 2019). The epiphragm layer has been reported to be a hardened mucus layer reinforced with lime carbonate (Struthers et al., 2002), 
consisting of $\mathrm{CaCO}_{3}$ in mineral phase, and containing approximately $1 \% \mathrm{MgCO}_{3}$ (Barnhart, 1983; Barnes, 1987; Struthers et al., 2002). The epiphragmal structure is a door that acts as a deterrent against predators and pathogens, physically protects the soft tissue of the snail in the shell against external factors and covers the aperture cavity (Ademolu et al., 2016). It has been reported that epiphragm formation is an important behavioral adaptation to resist stress during estivation in snails and is one of the water conservation strategies providing up to $20 \%$ water saving (Arad, 2001; Kingsolver, 2009). The ionic and organic composition of the Calcium carbonate-containing epiphragmal structure increases during estivation and hibernation (Ademolu et al., 2004; Abdussamad et al., 2010). The physiological basis of epiphragmal formation in snails consists of hemolymph which is rich in $\mathrm{Ca}^{2+}$ and $\mathrm{Mg}^{2+}$ (Ajayi et al., 2012; Akinnusi, 2014). A better understanding of the epiphragm layer will be beneficial for their cultivation. However, there is still a lack of information about epiphragm formation and mineralization in the literature. In the present study, the differences between the mineralization structure and formation durations of epiphragmal structure formed by $H$. pomacella, E. vermiculata, $H$. melanostoma, and $H$. asemnis to survive the hibernation period were investigated in the province of Hatay, Turkey, and the neighboring region.

\section{Materials and Method}

\section{Living Material Supply}

The snails used in the present study (Helix pomacella, Eobania vermiculata, Helix melanostoma, and Helix asemnis ) were collected from the high mountainous regions in Hatay's İskenderun, Arsuz and Dörtyol districts in September 2018, and brought to the İskenderun Technical University Faculty of Marine Sciences and Technology. Species identification of $H$. pomacella (11.1 $\pm 0.28 \mathrm{~g})$, E. vermiculata $(7.2 \pm 0.20 \mathrm{~g}), \mathrm{H}$. melanostoma $(14.3 \pm 0.27 \mathrm{~g})$ and $H$. asemnis $(17.4 \pm 0.21 \mathrm{~g})$ was carried out according to Schütt (1993).

\section{Hibernation Period}

The snails were placed in four 50x50x5 cm aquariums, called pans, which have a lid and are made of glass for easy observation in the laboratory. For snails to go through the hibernation process comfortably and stress-free, a habitat was created close to their natural environment. Pans were filled with 20 -cm-deep humus soil with $70 \%$ humidity and 25 snails were placed in each pan. Soil moisture was measured by tensiometer. Snails were fed with lettuce leaves in the form of free-feeding approximately for a month (until the end of October 2018) until the hibernation period. The research was observed November, December, January, February and March. The snails switched to hibernation in November 2018 and entered full hibernation at the end of November. The snails which started to wake up from hibernation became active in March 2019. The mineral composition (mg/g) of the epiphragm formed during the hibernation process was analyzed, in addition to weight $(\mathrm{g})$, thickness ( $\mathrm{mm})$, and formation duration (days) values.

\section{Hypometabolic Behavior Evaluation}

The hibernation period of snails was evaluated in three stages as entering hibernation, hibernation, and leaving hibernation stages. Hypometabolism behavior of snail species was evaluated according to the mobility conditions in the pans, the areas in which they were active in the pan, and the area where they had been fixed and underwent hibernation.

\section{Data Collection}

During the adaptation of the snails to the environment, morphometric measurements were carried out before entering the hibernation. Shell and aperture width measurement was measured according to Welter-Schultes (2012) using a digital caliper with a $0.01-\mathrm{mm}$-precision. A 0.1-g-precision digital scale was used for bodyweight measurement. Also, daily temperature, humidity, and precipitation values were recorded during the hibernation (November- December 2018, January-February 2019).

\section{Epiphragm Analysis}

Epiphragm layers formed in the aperture opening of the snails during the hibernation process were carefully collected using forceps and placed in clean Petri dishes. Following the weighing procedure, the epiphragm layers were powdered in a porcelain cup. For chemical analysis, $5 \mathrm{~g}$ ground epiphragm were analyzed for Calcium $\left(\mathrm{Ca}^{2+}\right)$, Iron $\left(\mathrm{Fe}^{2+}\right)$ and Phosphorus (P) contents using an Atomic Absorption Spectrophotometer (AAS) (Ademolu et al., 2016).

\section{Statistical Analysis}

In the present study, the Duncan Multiple Test was adopted to determine the relationship between snails' body measurements. The data obtained as a result of the research were evaluated according to the one-way analysis of variance (ANOVA).

\section{Results and Discussion}

\section{Hypometabolism Behavior}

Entering the Hibernation: Snails collected from nature in early September were not fed for the first 2 days after being placed in the pans. Starting from the third day, freefeeding was initiated by giving lettuce. The snails that were fed with lettuce pieces until the end of October showed the movement of wandering in the glass part of the pen. Among the species, E. vermiculata mostly preferred the soil area in the pan, few of them exhibited wandering behavior on the glass surface (Table 1). Comparing the species in terms of the formation duration (days) of the epiphragmal structure during the entering the hibernation period, it was determined that epiphragm formed the earliest ( $10 \pm 0.18$ days) in E. vermiculata whereas the latest (19 \pm 0.30 days) in $H$. asemnis (Table 7).

Hibernation period: In this period, which started in November 2018, most of the snails preferred to fix on the glass surface of the pan whereas $E$. vermiculata mostly fixed on the soil surface of the pan. The snails remained steady in the pan (Table, 2) in their preferred region (Table 2) for four months (November-December 2018, JanuaryFebruary 2019) and underwent hibernation (Table 7). 
Leaving the hibernation: At the beginning of March 2019, the snails were observed to leave hibernation. Examining in terms of mobility zones, the mobility observed on the glass surface of the pans generally took place in the soil area in E. vermiculata (Table 3). When the awakening from hibernation reached $50 \%$, snails were fed immediately (with lettuce). Among the snail species, $H$. pomacella was the first to wake up from hibernation and completed hibernation $100 \%$ on the 3rd day. E. vermiculata completed the hibernation $100 \%$ on the 7 th day (Table 4-5). Comparing the degradation of the epiphragmal structure that breaks at the end of the hibernation depending on the species, the epiphragmal structure of $H$. pomacella and $H$. asemnis is separated from the aperture cavity as a whole piece (Figures 1, 2, and 3). E. vermiculata disintegrated the epiphragmal structure and separated it from the aperture cavity. However, $H$. melanostoma had an epiphragmal structure that was generally divided into 2-3 parts at the end of the hibernation. Comparing the weight and thickness of the epiphragmal structure by species at the end of the hibernation, the weight $(0.025 \pm 0.28 \mathrm{~g})$ and thickness $(0.125 \pm 0.30 \mathrm{~mm})$ for E. vermiculata were the lowest whereas the highest values $(0.41 \pm 0.26 \mathrm{~g}, 0.310 \pm 0.22 \mathrm{~mm}$, respectively) were determined in $H$. asemnis (Table 7).

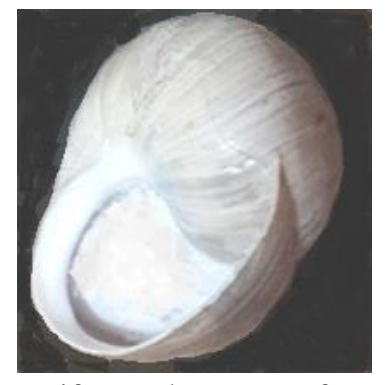

Figure 1. Epifragmal structure formed in the aperture cavity

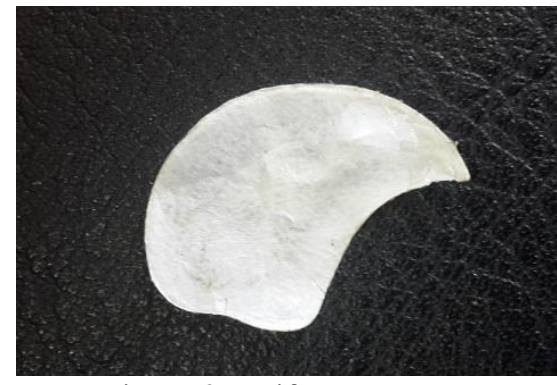

Figure 2. Epifragma Layer

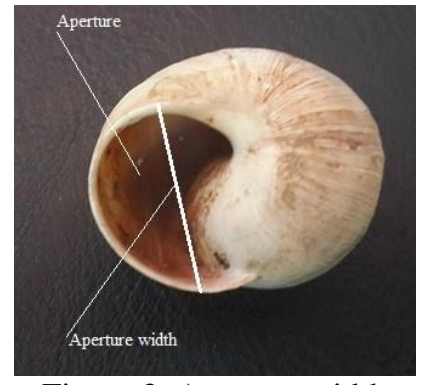

Figure 3. Aperture width

Table 1. Hypometabolism behavior of snails at the stage of entering the hibernation.

\begin{tabular}{|c|c|c|c|c|}
\hline \multirow[b]{2}{*}{ Species $(n=25)$} & \multicolumn{4}{|c|}{ Entering the hibernation (October 2018) } \\
\hline & $\begin{array}{l}\text { The Mobility } \\
\text { Area }\end{array}$ & $\begin{array}{c}\text { Choice of } \\
\text { Feeding Time }\end{array}$ & $\begin{array}{c}\text { Location and Frequency } \\
\text { of defecation }\end{array}$ & $\begin{array}{l}\text { The region where snails } \\
\text { hibernate in the pen }(\%)\end{array}$ \\
\hline Helix pomacella & $\begin{array}{l}\text { The glass surface } \\
\text { of the pan }\end{array}$ & $\begin{array}{l}\text { Morning, Noon, } \\
\text { Evening }\end{array}$ & Glass surface Continuous & None \\
\hline Eobania vermiculata & Soil area in the pan & Evening & Soil area During mobility & None \\
\hline Helix melanostoma & $\begin{array}{l}\text { Glass surface and } \\
\text { soil area of the pan }\end{array}$ & $\begin{array}{l}\text { Morning (early), } \\
\text { evening (late) }\end{array}$ & $\begin{array}{l}\text { Glass surface and soil } \\
\text { area, continuously }\end{array}$ & None \\
\hline Helix asemnis & $\begin{array}{l}\text { The glass surface } \\
\text { of the pan }\end{array}$ & $\begin{array}{l}\text { Morning (early), } \\
\text { evening (late) }\end{array}$ & $\begin{array}{l}\text { Glass surface } \\
\text { Continuously }\end{array}$ & None \\
\hline
\end{tabular}

Table 2. Hypometabolism behavior of snails during the hibernation stage.

\begin{tabular}{l|llll}
\hline \multirow{2}{*}{ Species $(\mathrm{n}=25)$} & \multicolumn{3}{|c}{ Hibernation Period (November-December 2018, January- February 2019) } \\
\cline { 2 - 5 } & $\begin{array}{c}\text { The Mobility } \\
\text { Area }\end{array}$ & $\begin{array}{c}\text { Choice of } \\
\text { Feeding Time }\end{array}$ & $\begin{array}{c}\text { Location and Frequency } \\
\text { of defecation }\end{array}$ & $\begin{array}{c}\text { The region where snails } \\
\text { hibernate in the pen. (\%) }\end{array}$ \\
\hline Helix pomacella & None & None & None & Glass surface $(80 \%)$ \\
Eobania vermiculata & None & None & None & Soil area (75\%) \\
Helix melanostoma & None & None & None & Glass surface and soil area (50\%) \\
Helix asemnis & None & None & None & Glass surface (90\%) \\
\hline
\end{tabular}

Table 3. Hypometabolism behavior of snails at the stage of leaving the hibernation.

\begin{tabular}{l|llll}
\hline \multirow{2}{*}{ Species $(\mathrm{n}=25)$} & \multicolumn{2}{|c}{ Leaving the hibernation (March 2019) } & & \\
\cline { 2 - 5 } Helix pomacella & The Mobility Area & Feeding Time & $\begin{array}{l}\text { Location and Frequency } \\
\text { of defecation }\end{array}$ & $\begin{array}{l}\text { The region where snails } \\
\text { hibernate in the pen }(\%)\end{array}$ \\
\hline Eobania vermiculata & The glass surface of & Morning (early) & $\begin{array}{l}\text { Glass surface } \\
\text { Continuously }\end{array}$ & None \\
\hline Helix melanostoma & $\begin{array}{l}\text { The glass surface of } \\
\text { the pan }\end{array}$ & $\begin{array}{l}\text { Morning (early), } \\
\text { noon, evening (late) }\end{array}$ & $\begin{array}{l}\text { Glass surface and } \\
\text { continuously }\end{array}$ & None \\
\hline Helix asemnis & $\begin{array}{l}\text { Mostly at the glass } \\
\text { surface and rarely at } \\
\text { the soil area of the pan }\end{array}$ & $\begin{array}{l}\text { Morning (early), } \\
\text { evening (late) }\end{array}$ & $\begin{array}{l}\text { Glass surface } \\
\text { Continuously }\end{array}$ & None \\
\hline
\end{tabular}


Table 4. Ratio of leaving the hibernation in snail species (\%).

\begin{tabular}{l|cccc}
\hline \multirow{2}{*}{ Leaving } & \multicolumn{3}{c}{ Species } \\
\cline { 2 - 5 } hibernation/Species & Helix pomacella & Eobania vermiculata & Helix melanostoma & Helix asemnis \\
\hline 1. Days & $30 \%$ & $5 \%$ & $25 \%$ & $15 \%$ \\
2. Days & $65 \%$ & $25 \%$ & $50 \%$ & $47 \%$ \\
3. Days & $100 \%$ & $48 \%$ & $73 \%$ & $62 \%$ \\
4. Days & $100 \%$ & $66 \%$ & $97 \%$ & $88 \%$ \\
5. Days & $100 \%$ & $81 \%$ & $100 \%$ & $96 \%$ \\
6. Days & $100 \%$ & $93 \%$ & $100 \%$ & $100 \%$ \\
7. Days & $100 \%$ & $100 \%$ & $100 \%$ & $100 \%$ \\
\hline
\end{tabular}

Table 5. Leaving the hibernation time and epiphragm decay in snail species.

\begin{tabular}{l|cl}
\hline $\begin{array}{c}\text { Species } \\
(\mathrm{n}=25)\end{array}$ & $\begin{array}{c}\text { Time to leave the hibernation } \\
(\text { days })\end{array}$ & $\begin{array}{c}\text { The shape of the epiphragmal structure that breaks } \\
\text { at the stage of leaving the hibernation }\end{array}$ \\
\hline Helix pomacella & $3 \pm 0.22^{\mathrm{c}}$ & Whole piece \\
Eobania vermiculata & $7 \pm 0.28^{\mathrm{a}}$ & Fractured \\
Helix melanostoma & $5 \pm 0.19^{\mathrm{b}}$ & Two and three pieces \\
Helix asemnis & $6 \pm 0.20^{\mathrm{b}}$ & Whole piece \\
\hline
\end{tabular}

In the present study, the weight values were compared between four snail species before and after hibernation and weight loss was determined after snails' efforts to survive without food for four months. Accordingly, the lowest weight loss was detected in $H$. asemnis (18\%) whereas the highest was in E. vermiculata (22\%) (Table 6).

\section{Mineral Composition of the Epiphragm Layer}

The mineral compositions were analyzed since the epiphragm is an important structure that protects the snails from cold weather conditions and protects it until the weather conditions become more suitable. Comparing the four species in terms of Calcium, Phosphorus and Iron, the highest Calcium level was determined in Helix asemnis (29.96 \pm 0.12$)$ whereas the lowest was determined in $H$. Pomacella (14.18 \pm 0.25$)$; the highest Phosphorus content was determined in E. vermiculata $(4.02 \pm 0.20)$ whereas the lowest Phosphorus content was in Helix melanostoma (2.98 \pm 0.24$)$, and the highest Iron content was in $H$. Pomacella (19.50 \pm 0.33$)$ whereas the lowest was determined in E. vermiculata (10.48 \pm 0.26$)$ (Table 8).

With the air temperature dropping below $20{ }^{\circ} \mathrm{C}$, the snails that formed the epiphragm layer entered hibernation. During this period, the lowest temperature averages in November, December, January, and February were $17.5^{\circ} \mathrm{C}$, $14^{\circ} \mathrm{C}, 12^{\circ} \mathrm{C}$, and $14^{\circ} \mathrm{C}$, respectively (Table 9). Thanks to the epiphragm layer formed during the hibernation process, hibernation ended with a high survival rate. The lowest survival rate was found in E. vermiculata (88\%) (Table 6).

Examining the morphometric values of the species, it was observed that there was a similarity in terms of size between the shell width and the aperture width (Table 6). Examining the aperture widths and the epiphragm weights (Table 2), it was determined that the epiphragm weight of the snail with a large shell was in line with its size. Examining the epiphragm formation period, it was observed that the smallest species E. vermiculata, completed in 10 days whereas the largest species $H$. asemnis completed this process in 19 days. It was determined that there was a direct proportion between epiphragm formation time and aperture width, and snails with large aperture had longer epiphragm formation times (Table 6,7). In terms of live weight, shell, and aperture width of snails, it was determined that $H$. asemnis was larger and there was a direct proportion between the aperture width and epiphragm weight and thickness (Tables 6 and 7).

Snails have been reported to exhibit physiological and biochemical adaptations to survive under stressful conditions, forming an epiphragm layer for the preservation of body water (Storey, 2002; Storey, 2007; Şereflişan, 2019; Şereflişan, 2020). In the present study, it was observed that in November when the temperature dropped below $20^{\circ} \mathrm{C}$, the movement of snails reduced, and epiphragm was formed in the aperture opening. Epiphragm formation is an adaptation model of the temperature factor (Kingsolver and Huey, 2008) that affects all life functions of organisms physiologically and biochemically (Malleswar et al., 2013). The movement, growth, development, and activity level of living things vary within critical temperature limits (Kingsolver, 2009). In the present study, the fact the snails that have become stationary to avoid being affected by the negative condition of the environment under conditions where the temperature drops below $20^{\circ} \mathrm{C}$ (Parallel to the negative conditions of the environment) was in line with those reported in the previous studies. Epiphragm formation was different because of their size of the snails.

In the previous studies, it has been reported that there were weight losses at the critical limits in the increase or decrease in temperature (Onadeko, 2010). In a study on the $\mathrm{Mg} / \mathrm{Ca}$ ratio, it has been reported that mineral salts were transported from the shell to the relevant cells and intestinal fluid during the estivation and hibernation period, and there may be a decrease in the thickness of the shell during this process (Porcel et al., 1996). In the present study, it was observed that when four different land snails started to feel the symptoms of hibernation, they formed the epiphragm layer at different durations (Table 7). In the present study, it was observed that there was a positive relationship between the aperture width and epiphragm formation time $(\mathrm{P}<0.05)$. 
Table 6. Comparison of live weight values of snails before and after hibernation.

\begin{tabular}{l|cccccc}
\hline \multicolumn{1}{c|}{ Species $(\mathrm{n}=25)$} & PRHB & PSHB & LWL & ST & AW & SR \\
\hline Helix pomacella & $11,1 \pm 0,28^{\mathrm{c}}$ & $8.88 \pm 0.18^{\mathrm{c}}$ & 20 & $26.8 \pm 0.22^{\mathrm{c}}$ & $14.3 \pm 0.19^{\mathrm{c}}$ & 97 \\
Eobania vermiculata & $7.2 \pm 0.20^{\mathrm{d}}$ & $5.62 \pm 0.23^{\mathrm{d}}$ & 22 & $17.1 \pm 0.29^{\mathrm{d}}$ & $7.9 \pm 0.25^{\mathrm{d}}$ & 88 \\
Helix melanostoma & $14.3 \pm 0.27^{\mathrm{b}}$ & $11.3 \pm 0.25^{\mathrm{b}}$ & 21 & $33.8 \pm 0.21^{\mathrm{b}}$ & $18.8 \pm 0.33^{\mathrm{b}}$ & 96 \\
Helix asemnis & $17.4 \pm 0.21^{\mathrm{a}}$ & $14.24 \pm 0.19^{\mathrm{a}}$ & 18 & $38.6 \pm 0.18^{\mathrm{a}}$ & $22.4 \pm 0.26^{\mathrm{a}}$ & 98 \\
\hline
\end{tabular}

PRHB: Pre-Hibernation Bodyweight (g) Average \pm SE, PSHB: Post Hibernation Bodyweight (g) Average \pm SE, LWL: Live weight loss (\%), ST: Shell Thickness (mm) Average \pm SE, AW: Aperture Width $(\mathrm{mm})$ Average \pm SE, SR: Survival Rate $(\%)$, Average values with a different superscript in the same column are significantly different $(\mathrm{P}<0.05)$.

Table 7. Epiphragm weight (g), thickness (mm), and formation time (days) in snails during hibernation.

\begin{tabular}{l|ccc}
\hline $\begin{array}{c}\text { Species } \\
(\mathrm{n}=25)\end{array}$ & $\begin{array}{c}\text { Epifragma formation } \\
\text { duration (days) }\end{array}$ & $\begin{array}{c}\text { Epifragma weight } \\
(\mathrm{g})\end{array}$ & $\begin{array}{c}\text { Epifragma thickness } \\
(\mathrm{mm})\end{array}$ \\
\hline Helix pomacella & $14 \pm 0.19^{\mathrm{b}}$ & $0.22 \pm 0.31^{\mathrm{b}}$ & $0.260 \pm 0.26^{\mathrm{b}}$ \\
Eobania vermiculata & $10 \pm 0.18^{\mathrm{c}}$ & $0.025 \pm 0.28^{\mathrm{d}}$ & $0.125 \pm 0.30^{\mathrm{c}}$ \\
Helix melanostoma & $15 \pm 0,22^{\mathrm{b}}$ & $0.13 \pm 0.30^{\mathrm{c}}$ & $0.280 \pm 0.28^{\mathrm{b}}$ \\
Helix asemnis & $19 \pm 0.30^{\mathrm{a}}$ & $0.41 \pm 0.26^{\mathrm{a}}$ & $0.310 \pm 0.22^{\mathrm{a}}$ \\
\hline
\end{tabular}

* Average values with a different superscript in the same column are significantly different $(\mathrm{P}<0.05)$.

Table 8. Mineral composition $(\mathrm{mg} / \mathrm{g}$ ) of the epiphragm layer formed in snails during the hibernation period.

\begin{tabular}{l|ccc}
\hline \multicolumn{1}{c|}{ Species } & Calcium $(\mathrm{mg} / \mathrm{g})$ & Phosphorus $(\mathrm{mg} / \mathrm{g})$ & Iron $(\mathrm{mg} / \mathrm{g})$ \\
\hline Helix pomacella & $14,18 \pm 0,25^{\mathrm{c}}$ & $3,02 \pm 0,22^{\mathrm{c}}$ & $19.50 \pm 0.33^{\mathrm{a}}$ \\
Eobania vermiculata & $22,15 \pm 0,23^{\mathrm{b}}$ & $4.02 \pm 0.20^{\mathrm{a}}$ & $10.48 \pm 0.26^{\mathrm{c}}$ \\
Helix melanostoma $_{\text {Helix asemnis }}^{20,24 \pm 0,23^{\mathrm{b}}}$ & $2.98 \pm 0.24^{\mathrm{c}}$ & $15.72 \pm 0.24^{\mathrm{b}}$ \\
\hline
\end{tabular}

* Average values with a different superscript in the same column are significantly different $(\mathrm{P}<0.05)$.

Table 9. Daily average temperature $\left({ }^{\circ} \mathrm{C}\right)$, humidity $(\%)$, and precipitation $(\mathrm{mm})$ values during the hibernation period (November-December 2018, January-February 2019).

\begin{tabular}{|c|c|c|c|c|c|}
\hline Daily & $\begin{array}{c}\text { November } \\
2018\end{array}$ & $\begin{array}{c}\text { December } \\
2018\end{array}$ & $\begin{array}{c}\text { January } \\
2019\end{array}$ & $\begin{array}{c}\text { February } \\
2019\end{array}$ & $\mathrm{SE}$ \\
\hline Maximum Temperature $\left({ }^{\circ} \mathrm{C}\right)$ & 29.1 & 22 & 20 & 22 & 0.22 \\
\hline Minimum Temperature $\left({ }^{\circ} \mathrm{C}\right)$ & 17.50 & 14 & 12 & 14 & 0.27 \\
\hline Daily Average Temperature $\left({ }^{\circ} \mathrm{C}\right)$ & 28.5 & 16.9 & 16 & 18.53 & 0.22 \\
\hline Humidity (\%) & 53 & 65 & 71 & 68 & 0.31 \\
\hline Daily Precipitation (mm) & 4.16 & 7.8 & 19.27 & 8.06 & 0.34 \\
\hline
\end{tabular}

The snail shell structure consists of calcium carbonate $\left(\mathrm{CaCO}_{3}\right)$ (Ademolu et al., 2004). The epiphragm layers of Achatina achatina and Archachatina marginata were analyzed in terms of Calcium, and it has been reported that the Ca content of A. achatina was $40.68 \pm 1.20 \mathrm{mg} / \mathrm{g} \mathrm{CaCO} 3$, and the highest Calcium content after Iron in A. marginata was $10.12 \pm 0.32 \mathrm{mg} / \mathrm{g}$ (Ademolu et al., 2016). In the present study, the epiphragmal structure of four land snail species was analyzed in terms of mineral composition and, in parallel with the literature, the Ca value was found to be high in all species except for $H$. pomacella. Ademolu et al. (2016), who stated that Phosphorus and Iron were important elements in the epiphragm mineral composition, found the Phosphorus content in A. achatina and A.marginata to be $4.26 \pm 0.13 \mathrm{mg} / \mathrm{g}$ and $4.10 \pm 1.01 \mathrm{mg} / \mathrm{g}$, respectively. In the present study, the phosphorus value of $E$. vermiculata among the four species was found to be similar with $4.02 \pm 0.18 \mathrm{mg} / \mathrm{g}$. In the study conducted by Ademolu et al. (2016), it has been stated that Iron was a high-level mineral in the epiphragm structure following Calcium, and found the Iron content in the epiphragm layers in A. achatina, A. marginata, and A. fulica to be $21.67 \pm 0.11 \mathrm{mg} / \mathrm{g}, 20.81 \pm 0.32$ $\mathrm{mg}$, and $15.72 \pm 0.10 \mathrm{mg} / \mathrm{g}$ respectively. The highest Iron value in the present study was in $H$. pomacella and $H$. Asemnis, with $19.50 \pm 0.33,18.94 \pm 0.28 \mathrm{mg} / \mathrm{g}$, respectively whereas the lowest was E. vermiculata with $10.48 \pm 0.26$ $\mathrm{mg} / \mathrm{g}$. Comparing the results of the ionic analysis of the epiphragm layer formed in four snail species during the estivation period by Şereflişan (2020) with the Calcium, Iron and Phosphorus results obtained in the present study (hibernation period), the Calcium, Phosphorus and Iron values of the epiphragm layer during the hibernation period (hibernation) were found to be lower than the estivation period. The formation time of the epiphragmal structure in $H$. pomacella, E. vermiculata, $H$. melanostoma and $H$. asemnis species has been reported to be $11 \pm 0.28$ days, $9 \pm 0.35$ days, $14 \pm 0.36$ days, and $15 \pm 0.22$ days, respectively (Şereflişan, 2020). Comparing the entering the hibernation period and the formation duration of the epiphragmal structure, and leaving the hibernation period and the degradation duration and of the epiphragmal structure, it was observed that the degradation of the epiphragm occurred in a shorter period (Tables 5 and 7).

\section{Conclusion}

According to the results, when the temperature dropped below $20^{\circ} \mathrm{C}$ (November 2018), the movements of $H$. pomacella, E. vermiculata, $H$. melanostoma, and $H$. asemnis were restricted and they entered hibernation. 
Against the stressful conditions created by this process, the epiphragmal structure, the defense model in the aperture opening, was created. Although the formation duration of this structure varies depending on the species, it was determined that it was directly proportional to the snail shell and aperture width. It was understood that the epiphragmal layer, which protects the body water of the snail and is an important isolation mechanism, has the highest level of Calcium in the mineral composition, followed by Iron. It was determined that mineral levels were not in line with aperture and shell width. Compared to previous studies in the literature, it was determined that the epiphragm formation duration of $H$. pomacella, E. vermiculata, $H$. melanostoma, and $H$. asemnis was shorter than their estivation period, and the level of calcium, Iron and Phosphorus of the epiphragmal structure was found to be lower. As a result, it was understood that the ecological tolerances of the snails that protect the body reserves through this structure depend on the epiphragmal structure and that epiphragm is an important part of a sustainable life cycle of these living things.

\section{References}

Abdussamad MA, Olusegun AO, Olusiji FS, Samuel AO. 2010. Some haemolymph biophysical parameters in the giant African land snail Archachatina marginata during a six-week aestivation period. Global Veterinaria, 4(4): 400-408.

Ademolu KO, Idowu AB, Mafiana CF, Osinnowo OA. 2004. Performance, proximate and minerals analysis of African giant land snail (Archachatina marginata) fed differentnitrogen sources. African Journals of Biotechnology, 3(8): 412-414.

Ademolu KO, Fantola FO, Bamidele JA, Dedeka GA, Idowu AB. 2016. Formation and composition of epiphragm in three giant African land snails (Archachatina marginata,Achatina fulica and Achatina achatina), Ruthenica, 26(3-4): 165-169.

Adeyeye EI, Afolabi EO. 2004. Amino acid composition of three different types of land snails consumed in Nigeria. Food Chemistry, 85: 535-539.

Ajayi OA, Fawole JK, Idowu AB, Ademolu KO. 2012. Dynamics of nutrient in the tissues of giant African land snail (Archachatina marginata) during aestivation. 1st International Conference on giant African land snails [GALS]. Held at Federal University ofAgriculture, Abeokuta, Nigeria on 12th-15th February 2012, pp. 67-71.

Akinnusi O. 1998. A practical approach to backyard snail farming. Nigeria Journal of Animal Production, 25: 85-95.

Akinnusi O. 2014. Snail production and management. Tolukoya publishing company, Abeokuta, Nigeria, $105 \mathrm{p}$.

Akman MAA, Yazar S, Şahin İ, Yıldırım Z. 2005. Kayseri karpuz sekisi havzasında tatlı su gastropodlarının araştırılması. Sağlık Bilimleri Dergisi, 14(1): 1-5.

Arad Z. 2001. Desiccation and rehydration in land snails - a test for distinct set points in Thebapisana. Israel Journal of Zoology, 47: 41-53.

Barnes RD. 1987. Invertebrate Zoology $5^{\text {th }}$ Edition. W. B. Saunders Company. p. 743.

Barnhart MC. 1983. Gas permeability of the epiphragm of a terrestrial snail, Otala lactea. Physiological Zoology, 56: 436-444.

Cook A. 2001. Behavioural ecology: On doing the right thing, in the right place at the righttime. InBarker, G. M. (Ed.): The Biology of Terrestrial Molluscs. CAB International. Wallingford. pp. 447-487.
Giokas S, Karkoulis P, Pafilis P, Valakos E. 2007. Relictual physiological ecology in the threatened land snail Codringtonia helenae: a cause for decline in a changing environment? Acta Oecologica, 32: 269-278.

Hermes-Lima M, Storey JM, Storey KB. 1998. Antioxidant defenses and metabolic depression. The hypothesis of preparation for oxidative stress in land snail. Comparative Biochemistry and Physiology B, 120: 437-448.

Kingsolver JG, Huey RB. 2008. Size, temperature, and fitness: three rules. Evolutionary Ecology Research, 10: 251-268.

Kingsolver JG. 2009. The well-temperatured biologist. (American Society of Naturalists Presidential Address). The American Naturalist, 174: 755-768.

Malcolm R, Liu C, Neilson RP, Hansen L, Hannah L. 2006. Global warming and extinction of endemic species from biodiversity hot spots. Conservation Biology, 20: 538-548.

Malleswar VNS, Basavaraju R, Krupanidhi S. 2013. Behavioral and Physiological Changes in Pila globosa (Indian Apple Snail) During Aestivation. Zoology, 2(8): 54-55.

Onadeko SA. 2010. Live weight changes and mortality rate in the giant african snail Archachatina marginata during six week aestivation period. World journal of Zoology,5(2): 75- 81 .

Odiete WD. 1999. Environmental physiology of animals and pollution. Diversified Resources Ltd. Surulere, Lagos. 95-97.

Omoyakhi JM. 2007. Effect of aestivation on growth, bady composition and reproductive performance of Giant African Land Snails, Archachatina margiata and Achatinaachatina $\mathrm{PhD}$ thesis. University of Agriculture Abeokuta, Nigeria.

Porcel D, Bueno JD, Almendros A. 1996. Alterations in the digestive gland and shell of the snail Helix aspersa Müller (Gastropoda, Pulmonata) after prolonged starvation. Comparative Biochemistry and Physiology Part A: Physiology, 115(1): 11-17.

Prior DJ. 1985. Water regulatory behaviour in terrestrial gastropods. Biological reviews of theCambridge Philosophical Society, 60: 403-424.

Schütt H. 1993. Türkische Landschnecken, Prodromus faunae Anatolicae molluscorumterrestrium viventium testaceorumque, Vorläufige Zusammenstellung der aus Anatolienbekannt gewordenen gehäusetragenden Landschnecken, Türkiye'nin karasalsalyangozları, pp. 1-433. Wiesbaden. (Hemmen).

Storey KB. 2001. Molecular mechanisms of metabolic arrest: life in limbo. BIO Scientifcpublishers Ltd. Oxford UK, 216 pp.

Storey KB. 2002. Life in the slow lane, molecular mechanisms of estivation. ComparativeBiochemistry and Physiology - Part A, 134: 733-754.

Storey KB. 2007. Tribute to P. L. Lutz: putting life on 'pause'-molecular regulation of hypo metabolism. Journal of Experimental Biology, 210(10): 1700-1714.

Struthers M, Rosair G, Buckman J, Viney C. 2002. The Phyircal and Chemical Microstructureof the Achatına Fulica Epiphragm. Journal of Molluscan Studies, 68:165-171

Şereflişan H. 2020. Epifragma Mineral Bileşiminin ve Oluşum Sürecinin Dört Kara Salyangozu Türünde (Mollusca: Gastropoda: Helicidae) İncelenmesi. Çanakkale Onsekiz MartÜniversitesi Fen Bilimleri Enstitüsü Dergisi, 6(1): 105111.

Şereflişan H. 2019. Biyoçeşitlilik Noktasında Kara Salyangozunun (Helix Aspersa) HayattaKalma Direnci. $1^{\text {st }}$ International Conference on Environment, Technology andManagement. 27-29 June/Niğde Halisdemir Üniversitesi, Environmental EngineeringDepartment/Niğde/ Turkey.

Welter-Schultes F. 2012. European non-marine molluscs, a guide for species identification.760 pages, ISBN 978-3-933922-755. 